\title{
A Review of Campylobacter Infections in Dogs
}

\author{
Sharon N Mbindyo ${ }^{1 *}$, Jafred MA Kitaa ${ }^{1}$, Gabriel O Aboge ${ }^{2}$, Tequiero O Abuom ${ }^{1}$ and Charles M Mulei ${ }^{1}$ \\ ${ }^{1}$ Department of Clinical Studies; ${ }^{2}$ Department of Public Health, Pharmacology and Toxicology, Faculty of Veterinary \\ Medicine, University of Nairobi, P.O. Box 29053-00625, Kangemi, Kenya \\ *Corresponding author: snmbindyo@gmail.com
}

Article History: 21-302 Received: 13-Apr-21 1 Revised: 30-Apr-21 Accepted: 2-May-21
ABSTRA C T
Campylobacter spp. are important bacterial enteropathogens that cause diarrhea in dogs with the predominant species
being Campylobacter jejuni, C. helveticus, and C. upsaliensis. Although campylobacteriosis is subclinical in many
dogs, some may develop moderate to mild enteritis. Puppies, kenneled dogs, and dogs with concurrent conditions are
highly susceptible to Campylobacter-associated diarrhea. Diagnosis of suspected Campylobacter-associated diarrhea
in dogs poses a challenge to veterinarians as the fecal enteric panels are costly, require technical knowledge, and are
time consuming, however molecular approaches for diagnosing the Campylobacter spp. infections are becoming
readily available and can help in accurate and fast diagnosis. Campylobacter spp. are amongst the prioritized human
and animal pathogens with regards to antimicrobial resistance. The rise and spread of antimicrobial resistance
threatens the effective treatment and control of Campylobacter infections. Multi-drug resistance Campylobacter spp.
have been isolated from dogs therefore treatment should only be administered where necessary. In conclusion,
understanding the epidemiology, diagnosis, treatment and zoonotic potential of Campylobacter spp. will enable small
animal practitioners include them among the differential diagnoses of diarrheic diseases in dogs.

Key words: Campylobacter infections, Dogs, AMR, Zoonotic.

\section{INTRODUCTION}

Campylobacter spp. are categorized as the motile, rod or spiral-shaped, gram-negative and fastidious bacteria that require a microaerophilic environment for growth (Corry and Atabay 2001; Kaakoush et a1. 2015). They do not form spores and are $0.2-0.8 \mu \mathrm{m}$ by $0.5-5 \mu \mathrm{m}$ in size, and they obtain their energy source from the intermediate cycle of tricarboxylic acid or amino acids (Vandamme et al. 2005). The Campylobacter genus belongs to the family Campylobacteraceae, order Campylobacterales, class Epsilonproteobacteria and phylum Proteobacteria (Fitzgerald and Nachamkin 2011).

Campylobacter spp. are important bacterial enteropathogens that cause diarrhea in dogs (Guilford and Strombeck 1996; Cave et a1. 2002) with the predominant species being Campylobacter jejuni, C. helveticus and $C$. upsaliensis (Parsons et al. 2010; Marks et a1. 2011). Human pathogens like C. coli, C. lari, C. gracilis, $C$. mucolas, C. showae, C. fetus, C. concisus, and $C$. sputorum have also been isolated in dog feces (Chaban et al. 2010).

Campylobacter spp. are primary zoonotic pathogens that cause gastroenteritis globally (Havelaar et al. 2015;
FSA 2017). Most infections are caused by thermotolerant C. jejuni, C. upsaliensis, C. coli and other species (Lastovica and Skirrow 2000; Labarca et al. 2002; Lastovica and le Roux 2003; Galanis 2007; Noreen et al. 2019; Gahamanyi et al. 2020).

Although dogs of all ages can be affected, puppies one year and below have a high prevalence (Hald et al 2004; Chaban et al. 2010) which varies depending on the study design, sampled population and the detection method (Iannino et al. 2017). Consuming or handling undercooked/contaminated meat (poultry to be specific) is the key source for human Campylobacter infections (Adak et a1. 2005; Strother 2005; Hermans et a1. 2012; Sahin et a1. 2015). Contact with dogs has also been implicated as a risk for Campylobacter infections in children (Tenkate et a1. 2001; Mughini et a1. 2013).

Diagnosis of suspected Campylobacter-associated diarrhea in dogs is based on fecal panel test results (Marks et a1. 2011). However, the use of these fecal panels (culture and direct PCR) poses a challenge to veterinarians as the fecal enteric panels are costly, time-consuming and require technical skill (Marks and Kather 2003). The methods of detection used in Campylobacter spp. diagnosis of the infections in laboratories are biased towards the

Cite This Article as: Mbindyo SN, Kitaa JMA, Aboge GO, Abuom TO and Mulei CM, 2021. A review of Campylobacter infections in dogs. International Journal of Veterinary Science 10(4): 259-266. https://doi.org/10.47278/journal.ijvs/2021.057 
pathogenic $C$. jejuni, resulting in the under-diagnosis of the other Campylobacter spp. This challenge has confirmed the importance of culture-based research advances and Campylobacter spp. molecular detection (Chaban et al. 2010; Kaakoush et al. 2015; Bojanić et a1. 2016; Buss et al. 2019).

The emergence and dissemination of multidrugresistant (MDR) Campylobacter spp. is a result of the widespread use of antimicrobials in the treatment of Campylobacter- associated diarrhea (Fitzgerald 2008) and therefore the prudent use of antibiotics (enrofloxacin and the macrolides (erythromycin and azithromycin)] is advised, as many cases resolve with supportive therapy (Marks 2003).

This paper reviews epidemiology, diagnostic workup, treatment, antimicrobial resistance, and the public health importance of Campylobacter infections in dogs.

\section{Epidemiology of Campylobacter Infections in Dogs}

In animals, Campylobacter spp. transmission is through indirect or direct fecal-oral route, with infection sources from raw or undercooked food, fresh feces from fomites, infected animals, environment, and when incontact with animals that are infected (Acke 2018). Numerous studies on the prevalence of Campylobacter spp. have been conducted in different countries (Table 1) and it varies depending on the age, the housing, geographic region, study design, diarrheic versus healthy dogs, the method of diagnosis, and the presence of infection or concomitant disease with enteropathogenic bacteria.

Pintar et a1. (2015) conducted a meta-analysis research considering 34 publications that described the prevalence of Campylobacter spp. in pet animals and an average prevalence of $24.7 \%$ was reported in household cats and dogs. The study noted that lack of standardization of methods significantly complicated the interpretation of results thus confirming gaps in the knowledge which exists in the significant Campylobacter spp. infections and its effect on humans.

\section{Factors Associated with Campylobacter spp. Prevalence in Dogs \\ Signalment}

Several studies reported that puppies had a high prevalence in comparison with the adult dogs (Parsons et al. 2010; Leonard et al. 2011; Rahimi et al. 2012; Kumar et al. 2012; Holmberg et al. 2015; Selwet et al. 2015; Thépault et al. 2020), this may be an indication that they lack prior exposure to the immune system. There is no proof of any sex or animal breed predispositions in the literature published so far.

\section{Intensive Housing}

Kenneled dogs that are immunocompromised are more likely to be positive to Campylobacter spp. on culture than pet dogs (Marks 2003; Workman et al. 2005; Parsons et al. 2011; Acke 2018). This is probably due to the stress, dietary variation, and close interaction with other animals (Marks et al. 2011; Parsons et al. 2011; Giacomelli et al. 2015; Leahy et al. 2016). Poor kennel conditions provide an environment conducive to the propagation of Campylobacter spp.

\section{Presence of Intestinal Disease}

Chaban et a1. (2010) reported that diarrheic dogs had a higher Campylobacter spp. prevalence in comparison with the healthy dogs. However, some studies demonstrated an insignificant difference in the prevalence of Campylobacter spp. from diarrheic or healthy dogs (Duijvestijn et al. 2016; Suchodolski et al. 2010; Leahy et al. 2017), which may be an indication of the frequency of subclinical infections.

In a study conducted by Olson and Sandstedt (1987), dogs were infected experimentally with $C$. upsaliensis and $C$. jejuni, one out of the three dogs infected with $C$. upsaliensis passed soft feces whereas one out of the three dogs infected with $C$. jejuni developed diarrhea. In addition, puppies orally inoculated with $C$. jejuni developed mild symptoms of enteritis (Macartney et a1. 1988).

Parasitic or viral enteritis has also been suggested to predispose dogs to Campylobacter spp. infection (Brown et a1. 1999). Clinical signs may develop in dogs with preexisting or concurrent diseases (Brown et a1. 1999).

\section{Diet}

Majority of the pet owners feed purchased or homemade raw meat diets which pose a high risk for the dogs and humans handling the meat as it is frequently contaminated with these organisms (Fredriksson-Ahomaa et al. 2017). Puppies fed on a homemade food diet are also at a risk for Campylobacter infection (Leonard et a1. 2011). This increases the fecal shedding of the organism thus increases the risk of spread to other pets, domestic animals and humans especially those who are at a high risk due to age or immunosuppression. To reduce this risk, raw meat diets should not be fed to dogs. When handling the meat prior to cooking, handwashing is encouraged together with disinfecting any surfaces that have come in contact with the raw meat.

\section{Infection with Multiple Campylobacter spp.}

Multiple Campylobacter spp. identified from fecal samples by direct polymerase chain reaction (PCR) and/or bacterial is highly common (Kulkarni et al. 2002; Chaban et al. 2010; Kaakoush et al. 2015; Bojanić et al. 2017). The complex epidemiology of canine campylobacteriosis has been demonstrated by the confirmation of genetic heterogeneity within several Campylobacter spp. (Koene et al. 2009; Parsons et a1. 2010; Amar et a1. 2014; Bojanić et a1. 2017; Thépault et al. 2020). Introgression among multiple Campylobacter spp. may lead to pathogen adaptation, higher pathogenicity and antimicrobial resistance.

\section{Concomitant Campylobacter spp. Infection with Other Organisms}

Concomitant Campylobacter spp. infection with organisms such as parvovirus (Olson and Sandstedt 1987; Workman et al. 2005) and Helicobacter spp. (Rossi et al. 2008) has been reported. Direct PCR performed on fecal samples in healthy dogs from dog parks revealed Campylobacter spp. co-infection with coronavirus, circovirus, Clostridium spp., as well as Cryptosporidium spp. (Hascall et a1. 2016). Co-infection of Campylobacter 
Int J Vet Sci, 2021, 10(4): 259-266.

Table 1: Prevalence of Campylobacter spp. in dogs across the globe from different studies

\begin{tabular}{|c|c|c|c|}
\hline Study/Reference & Prevalence $(\%)$ & Species isolated & Country \\
\hline Fernandez and Martin (1991) & 42.5 & C. jejuni, $C$. coli & Chile \\
\hline Baker et al. (1999) & 43 & C. jejuni, C. upsaliensis, C. coli & Australia \\
\hline Hald et al. (2004) & 76 & C. jejuni, C. upsaliensis, C. coli, C. lari & Denmark \\
\hline Tsai et al. (2007) & 2.8 & C. jejuni, C. upsaliensis, $C$. coli & China \\
\hline Rossi et al. (2008) & 30.2 & C. jejuni, C. upsaliensis, $C$. helveticus, $C$. lari & Italy \\
\hline Parsons et al. (2010) & 38 & C. jejuni, C. upsaliensis & UK \\
\hline Chaban et al. (2010) & 56 & Multiple spp. & Canada \\
\hline Carbonero et al. (2012) & 35.2 & C. jejuni, C. upsaliensis & Spain \\
\hline Holmberg et al. (2015) & 37 & C. upsaliensis, C. jejuni, C. helveticus & Sweden \\
\hline Begum et al. (2015) & 60 & C. jejuni, C. coli & Ethiopia \\
\hline Rodrigues et al. (2015) & 19.4 & C. jejuni, C. coli & Brazil \\
\hline Bojanić et al. (2016) & 36 & C. jejuni, C. upsaliensis, C. helveticus, C. lari & New Zealand \\
\hline Karshima and Bobbo (2016) & 23.8 & C. jejuni, C. coli & Nigeria \\
\hline Conan et al. (2017) & 10 & C. jejuni, C. coli & Kenya \\
\hline Ahmed et al. (2018) & 28.4 & C. jejuni & India \\
\hline Komba (2018) & $\begin{array}{c}20.9 \\
9.9\end{array}$ & C. jejuni & Tanzania \\
\hline Polzler et al. (2018) & 3.7 & C. jejuni, C. upsaliensis & Austria \\
\hline Karama et al. (2019) & 47.8 & C. jejuni, C. coli, C. upsaliensis & South Africa \\
\hline
\end{tabular}

spp. with other organisms may impact on the progression on Campylobacter infection in dogs from mild to severe and may increase the incidence of multidrug resistant organisms.

\section{Intermittent Shedding and Transient Infection}

The shedding of Campylobacter spp. is either intermittent or transient. A study by Hald et al. (2004) reported a high shedding prevalence in puppies less than a year old. They also reported that the shedding of $C$. upsaliensis was more continuous over a long period in comparison to $C$. jejuni suggesting the commensalism nature of $C$. upsaliensis and a transient $C$. jejuni infection (Hald et al. 2004). A similar finding was noted in kenneled dogs by Parsons et al. (2011). The intermittent shedding of homogenous Campylobacter spp. strains in several dogs has been determined by pulsed-field gel electrophoresis (Hald et al. 2004).

\section{Clinical Signs}

Campylobacter jejuni, $C$. helveticus, and $C$. upsaliensis are the main Campylobacter spp. in dogs (Workman et a1. 2005; Parsons et a1. 2010). Although majority of dogs may be subclinically infected, some dogs especially puppies less than 6 months of age or those from stressful environments may develop moderate to mild enteritis presenting as mild to watery diarrhea or as bloody or mucoid diarrhea with tenesmus (Brown et al. 1999; Chaban et al. 2010; Weese 2011; Acke 2018). Other reported clinical signs include anorexia, dehydration, lethargy and rarely fever, vomiting and abdominal pain (Brown et al. 1999; Sykes and Marks 2013; Marks et al. 2011).

Extra-intestinal Campylobacter infections include cholecystitis and cholangiohepatitis (Oswald et al. 1994; Center 2009; Sykes and Marks 2013). Campylobacter upsaliensis has been associated with acute polyradiculoneuritis (APN) (Martinez-Anton et a1. 2018) while $C$. jejuni infection has been linked to abortion (Odendaal et a1. 1994) and perinatal death (Sahin et al. 2014).

Barko et al. (2018) suggested that Campylobacter spp. may cause canine inflammatory bowel disease (cIBD) however, prospective studies to determine the importance of Campylobacter spp. in IBD pathogenesis are warranted (Maunder et a1. 2016). Campylobacter spp. were also found in samples of saliva from dogs with oral disease, a likely indication of these organisms plays a role in the pathogenesis of the condition (Petersen et a1. 2007; Yamasaki et al. 2012).

\section{Diagnosis}

Campylobacter spp. are either primary or secondary pathogens therefore isolation of these organisms is not a diagnosis of canine campylobacteriosis and concurrent or underlying diseases should be considered (Marks and Kather 2003; Acke 2018). For complicated cases, blood samples should be collected for hematology and serum biochemistry (Allenspach 2013; Sykes and Marks 2013) and diagnostic imaging done when extra-intestinal signs are present (Mapletoft et al. 2018).

\section{Fecal Examination}

In cases of $C$. jejuni enteritis, it is possible to see gram negative, slender, gull-wing rods and leukocytes on fecal gram stains (Marks et a1. 2011) and curved bacteria with a darting motion on phase-contrast or dark-field microscopy (Marks and Kather 2003). However, a microscopic morphological diagnosis alone cannot be validated, and further assessment is required (Marks et a1. 2011). Other infectious causes of diarrhea such as, helminths should also be evaluated (Allenspach 2013).

\section{Bacterial Isolation}

In cases where there are signs of enteritis, 2-3g fresh feces or rectal swabs in Cary Blair or Amies transport media are submitted to the laboratory for culture (Marks et a1. 2011). Various selective media for isolation of Campylobacter spp. from samples in modified atmospheric environments with a temperature range of 37 to $42^{\circ} \mathrm{C}$ have been described, for example, modified Charcoal Cefoperazone Deoxycholate Agar (mCCDA) medium for the isolation of $C$. coli and C. jejuni (GunMunro et a1. 1987), an agar with Cefoperazone, Amphotericin and Teicoplanin (CAT) for the isolation of C. coli, C. lari, C. helveticus, C. upsaliensis, and C. jejuni (Acke et al. 2009; Bojanić et al. 2017), and a filtration 
technique with blood agar for $C$. sputorum, $C$. curvus, $C$. concisus, and $C$. rectus isolation (Lastovica and le Roux 2000; Lastovica 2006; Kaakoush et al. 2015).

Matrix-Assisted Laser Desorption Ionization-Time of Flight (MALDI-TOF) mass spectrometry is an inexpensive, precise, and rapid method applied in commercial diagnostic laboratories for Campylobacter spp. identification and typing, and the detection of antibiotic resistance (Kiehntopf et a1. 2011; Singhal et al. 2015).

\section{Molecular Diagnosis \\ Detection of Campylobacter spp. using Molecular Methods}

Molecular methods are the yardstick for the detection, speciating, and typing of organisms and they have enhanced the diagnostic capabilities of veterinary diagnostic laboratories (Adzitey et al. 2013; On 2013; Cai et al. 2014; Kaakoush et al. 2015). Multiplex PCR confirms Campylobacter spp. from fecal samples isolated on bacterial culture (Persson and Olsen 2005; Neubauer and Hess 2006) whereas real-time PCR detects these organisms from feces without prior bacterial culture (Chaban et al. 2009, Chaban et al. 2010). Campylobacter in saliva from dogs have been detected by PCRdenaturing gradient gel electrophoresis (Petersen et al. 2007). Rapid and accurate detection of Campylobacter spp. in dogs is critical for appropriate treatment.

\section{Sub-Typing of Campylobacter spp. Strains}

Multilocus Sequence Typing (MLST) is a "gold standard" sub-typing technique used for the identification of $C$. helveticus, $C$. upsaliensis, $C$. coli, and $C$. jejuni from clinical samples without prior bacterial culture (Dingle et al. 2001; Workman et al. 2005; Taboada et a1. 2013; On 2013). Amplification and sequencing of (seven) housekeeping genes are done for MLST and alleic numbers are allocated in comparison with the PubMLST databases (http://pubmlst.org/campylobacter/) (Dingle et al. 2001; Workman et al. 2005; Taboada et al. 2013; Holmberg et al. 2015). According to Cantero et al. (2018), whole-genome sequencing differentiates strains and also identifies the antimicrobial resistant and virulent determinants in Campylobacter spp.

\section{Antimicrobial Therapy and Multidrug-Resistant Campylobacter Infections}

Prudent use of antibiotics in animals with suspected Campylobacter-associated diarrhea is advised for febrile or immunocompromised patients, or where the infection is severe or is extra-intestinal (Marks 2003; Marks et al. 2011). In dogs, erythromycin (10-15mg/kg orally every 8 hours) (Marks et al. 2011; Weese 2011), or azithromycin (5-10 mg/kg orally every 24 hours) (Marks et al. 2011) has been recommended in cases where susceptibility results are unavailable.

Multi-drug resistance Campylobacter spp. have been isolated from dogs therefore treatment should only be administered where necessary (Fitzgerald 2008; Marks et al. 2011; Kumar et al. 2012; Cho et al. 2014; Rodrigues et al. 2015; Ahmed et al. 2018). In the United States, multistate outbreaks of multidrug-resistant Campylobacter infections have been reported in humans linked to contact with puppies from pet stores (Montgomery 2018).

Prognosis of canine Campylobacter infections is very good when the treatment is appropriate and in the absence of systemic complications. In cases of treatment failure, reinfection, incorrect diagnosis, the intermittent shedding of Campylobacter spp., strain variations, and the development of antimicrobial resistant strains should be considered (Marks et al. 2011; Kaakoush et al. 2015; Acke 2018).

\section{Public Health Importance}

Campylobacter spp. are among the leading zoonotic pathogens causing gastroenteritis worldwide (Havelaar et al. 2015; Kaakoush et al. 2015; EFSA 2017). The main Campylobacter spp. in dogs: Campylobacter jejuni, C. helveticus and $C$. upsaliensis are considered sources of human Campylobacter infection (Labarca et al. 2002; Gras et al. 2013; Kaakoush et al. 2015; Bojanić et al. 2017). Approximately 9\% of human Campylobacter infections from pet animals are caused by direct fecal contact (Tam et al. 2009; Kittl et al. 2013; Mughini et al. 2013). The presence of puppies in the household has been implicated as a risk for Campylobacter infection in children (Tenkate and Stafford 2001; Mughini et al. 2013).

A study by Wolfs et al. (2001) in Netherlands showed evidence of transmission of $C$. jejuni from a household puppy to a 3-week-old infant. Transmission of the Campylobacter spp. can also be from infected humans to dogs. A study done in Denmark by Damborg et al. (2004) showed that $C$. jejuni could occur among pet dogs living with infected children. In humans, the reported clinical signs of Campylobacter infections include fever, abdominal pain, diarrhea, extraintestinal infections such as bacteremia and meningitis, and post-infectious conditions such as reactive arthritis and irritable bowel syndrome (Janssen et al. 2008; Fitzgerald 2015; Kaakoush et al. 2015).

\section{Conclusion}

Canine campylobacteriosis is a significant bacterial disease of public health importance with varying prevalence rates of the causative Campylobacter spp. from country to country. Multi-drug resistance Campylobacter spp. have been isolated from dogs therefore treatment is recommended where the infections are severe or are extra-intestinal. As molecular approaches which are fast and precise for diagnosing Campylobacter infections have become readily available, improved understanding of the epidemiology, diagnosis, treatment and zoonotic potential of Campylobacter spp. will enable small animal practitioners include them among the differential diagnoses of diarrheic diseases in dogs and implement effective preventive and control measures.

\section{REFERENCES}

Acke E, 2018. Campylobacteriosis in dogs and cats: a review. New Zealand Veterinary Journal, 66: 221-228. https://doi.org/10.1080/00480169.2018.1475268

Acke E, McGill K, Golden O, Jones BR, Fanning S and Whyte $\mathrm{P}, 2009$. A comparison of different culture methods for the 
recovery of Campylobacter species from pets. Zoonoses Public Health 56: 490-495. https://doi.org/10.1111/j.18632378.2008.01205.x

Adak GK, Meakins SM, Yip H, Lopman BA and O'Brien SJ, 2005. Disease risks from foods, England and Wales, 1996-2000. Emerging Infectious Diseases 11: 365-372. https://dx.doi.org/10.3201\%2Feid1103.040191

Adzitey F, Huda N and Ali GR, 2013. Molecular techniques for detecting and typing of bacteria, advantages and application to foodborne pathogens isolated from ducks. 3 Biotech 3: 97-107. https://dx.doi.org/10.1007\%2Fs13205-012-0074-4

Ahmed I, Verma AK and Kumar A, 2018. Prevalence, associated risk factors and antimicrobial susceptibility pattern of Campylobacter species among dogs attending veterinary practices at Veterinary University, Mathura, India. Veterinary Animal Science 6: 6-11. https://doi.org/ 10.1016/j.vas.2018.07.001

Allenspach K, 2013. Diagnosis of small intestinal disorders in dogs and cats. Veterinary Clinics North America: Small Animal Practice 43: 1227-1240. https://doi.org/10.1016/ j.cvsm.2013.07.001

Amar C, Kittl S, Spreng D, Thomann A, Korczak BM, Burnens AP and Kuhnert P, 2014. Genotypes and antibiotic resistance of canine Campylobacter jejuni isolates. Veterinary Microbiology 168: 124-130. https://doi.org/ 10.1016/j.vetmic.2013.10.006

Baker J, Barton MD and Lanser J, 1999. Campylobacter species in cats and dogs in South Australia. Australian Veterinary Journal 77: 662-666. https://doi.org/10.1111/j.17510813.1999.tb13159.x

Barko PC, McMichael MA, Swanson KS and Williams DA, 2018. The gastrointestinal microbiome: a review. Journal of Veterinary Internal Medicine 32: 9-25. https://doi.org/ $10.1111 /$ jvim. 14875

Begum S, Sekar M, Gunaseelan L, Gawande M, Suganya G, Malar PA and Karthikeyan A 2015. Molecular identification of Campylobacter jejuni and coli from chicken, calves and dogs to determine its potential threat on human being. Veterinary World 8: 1420-1423. https://doi.org/10.14202/vetworld.2015.1420-1423

Bojanić K, Midwinter AC, Marshall JC, Rogers LE, Biggs PJ and Acke E, 2016. Variation in the limit-of-detection of the prospect Campylobacter microplate enzyme immunoassay in stools spiked with emerging Campylobacter species. Journal Microbiology Methods 127: 236-241. https://doi.org/10.1016/j.mimet.2016.06.016

Bojanić K, Midwinter AC, Marshall JC, Rogers LE, Biggs PJ and Acke E, 2017. Isolation of Campylobacter spp. from client-owned dogs and cats, and retail raw meat pet food in the Manawatu, New Zealand. Zoonoses Public Health 64: 438-439. https://doi.org/10.1111/zph.12323

Brown C, Martin V and Chitwood S, 1999. An outbreak of enterocolitis due to Campylobacter spp. in a beagle colony. Journal of Veterinary Diagnostics 11: 374-376. https://doi.org/10.1177\%2F104063879901100416

Buss JE, Cresse M, Doyle S, Buchan BW, Craft DW, Young S, 2019. Campylobacter culture fails to correctly detect Campylobacter in $30 \%$ of positive patient stool specimens compared to non-cultural methods. European Journal Clinical Microbiology Infectious Diseases 38: 1087-1093. https://doi.org/10.1007/s10096-019-03499-x

Cai HY, Caswell JL and Prescott JF, 2014. Nonculture molecular techniques for diagnosis of bacterial disease in animals: A diagnostic laboratory perspective. Veterinary Pathology 51: 341-350. https://doi.org/10.1177\%2F030098 $\underline{5813511132}$

Cantero G, Correa-Fiz F, Ronco T, Strube M, Cerda-Cuellar M and Pedersen K, 2018. Characterization of Campylobacter jejuni and Campylobacter coli broiler isolates by whole- genome sequencing. Foodborne Pathogens and Disease 15: 145-152. https://doi.org/10.1089/fpd.2017.2325

Carbonero A, Torralbo A, Borge C, García-Bocanegra I, Arenas A and Perea A, 2012. Campylobacter spp., C. jejuni and C. upsaliensis infection-associated factors in healthy and ill dogs from clinics in Cordoba, Spain. Screening tests for antimicrobial susceptibility. Comparative Immunology, Microbiology \& Infectious Diseases 35: 505-512. https://doi.org/10.1016/j. cimid.2012.05.002

Cave NJ, Marks SL, Kass PH, Melli AC and Brophy MA, 2002. Evaluation of a routine diagnostic fecal panel in dogs with diarrhea. Journal of the American Veterinary Medical Association 221: 52-59. https://doi.org/10.2460/javma. 2002.221.52

Center SA, 2009. Diseases of the gallbladder and biliary tree. Veterinary Clinics North America Small Animal Practice 39: 543-598. https://doi.org/10.1016/j.cvsm.2009.01.004

Chaban B, Musil KM, Himsworth CG and Hill JE, 2009. Development of cpn60-based real-time quantitative PCR assays for the detection of 14 Campylobacter species and application to screening of canine fecal samples. Applied Environmental Microbiology 75: 3055-3061. https://doi.org/10.1128/aem.00101-09

Chaban B, Ngeleka M and Hill JE, 2010. Detection and quantification of 14 Campylobacter species in pet dogs reveals an increase in species richness in feces of diarrheic animals. BMC Microbiology 10: 73. https://doi.org/10. 1186/1471-2180-10-73

Cho H, Kim S, Min W, Ku B, Kim J and Kim Y, 2014 Characterization of antimicrobial resistance and application of RFLP for epidemiological monitoring of thermophilic Campylobacter spp. isolated from dogs and humans in Korea. Korean Journal of Veterinary Research 54: 91-99. https://doi.org/10.14405/kjvr.2014.54.2.91

Conan A, O'Reilly CE, Ogola E, Ochieng JB, Blackstocj AJ et al., 2017. Animal-related factors associated with moderateto-severe diarrhea in children younger than five years in western Kenya: A matched case-control study. PLOS Neglected Tropical Diseases 11: e0005795. https://doi.org/ 10.1371/journal.pntd.0005795

Corry $\mathbf{J}$ and Atabay H, 2001. Poultry as a source of Campylobacter and related organisms. Journal of Applied Microbiology 90: 96S-114S. https://doi.org/10.1046/j.13652672.2001.01358.x

Damborg P, Olse KE, Nielsen EM and Guardabassi L, 2004. Occurrence of Campylobacter jejuni in pets living with human patients infected with $C$. jejuni. Journal of Clinical Microbiology 42: 1363-1364. https://doi.org/10.1128/ jem.42.3.1363-1364.2004

Dingle KE, Colles FM, Wareing DR, Ure R, Fox AJ, Bolton FE, Bootsma HJ, Willems RJ, Urwin R and Maiden MC, 2001. Multilocus sequence typing system for Campylobacter jejuni. Journal of Clinical Microbiology 39: 14-23. https://doi.org/10.1128/jcm.39.1.14-23.2001

Duijvestijn M, MughiniGras L, Schuurman N, Schijf W, Wagenaar JA and Egberink H, 2016. Enteropathogen infections in canine puppies: (co-)occurrence, clinical relevance and risk factors. Veterinary Microbiology 195: 115-122. https://doi.org/10.1016/j.vetmic.2016.09.006

European Food Safety Agency (EFSA), 2017. The European Union Summary Report on antimicrobial resistance in zoonotic and indicator bacteria from humans, animals and food in 2015. EFSA Journal 13: 178. https://doi.org/ $10.2903 /$ j.efsa.2017.4694

Fernandez $\mathrm{H}$ and Martin R, 1991. Campylobacter intestinal carriage among stray and pet dogs. Revista de Saude Publica 25: 473-475. https://doi.org/10.1590/S0034$\underline{89101991000600009}$

Fitzgerald $\mathrm{C}$ and Nachamkin I, 2011. Campylobacter and Arcobacter. In: Versalovic J, Carroll K, Funke G, Jorgensen 
J, Landry ML, Warnock DW, eds. Manual of Clinical Microbiology. Washington DC: ASM Press pp: 885-899. https://doi.org/10.1128/9781555817381.ch56

Fitzgerald C, 2015. Campylobacter. Clinics in Laboratory Medicine 35: 289-298. https://doi.org/10.1016/j.cll.2015. $\underline{03.001}$

Fitzgerald F, Whichard J and Nachamkin I, 2008. "Diagnosis and antimicrobial susceptibility of Campylobacter species," in Campylobacter, Nachamkin I, Szymanski CM, and Blaser MJ, eds., American Society for Microbiology, Washington, DC, USA pp: 227-243. https://doi.org/ $\underline{10.1155 / 2013 / 340605}$

Fredriksson-Ahomaa M, Heikkila T, Pernu N, Kovanen S, Hielm-Bjorkman A and Kivisto R, 2017. Raw meat-based diets in $\operatorname{dogs}$ and cats. Veterinary Science 4: 33. https://doi.org/10.3390/vetsci4030033

Gahamanyi N, Mboera LEG, Matee MI, Mutangana D and Komba EVG, 2020. Prevalence, risk factors, and antimicrobial resistance profiles of thermophilic campylobacter species in humans and animals in SubSaharan Africa: A systematic review. International Journal of Microbiology 2020: Article ID 2092478. https://doi.org/10.1155/2020/2092478

Galanis E, 2007. Campylobacter and bacterial gastroenteritis. CMAJ 177: 570-571. https://dx.doi.org/10.1503\%2Fcmaj. $\underline{070660}$

Giacomelli M, Follador N, Coppola LM, Martini M and Piccirillo A, 2015. Survey of Campylobacter spp. in owned and unowned dogs and cats in northern Italy. Veterinary Journal 204: 333-337. https://doi.org/10.1016/j.tvj1.2015. $\underline{03.017}$

Gras LM, Smid JH, Wagenaar JA, Koene MG, Havelaar AH, Friesema IH, French NP, Flemming C, Galson JD, Graziani C, Busani L and van Pelt W, 2013. Increased risk for Campylobacter jejuni and $C$ coli infection of pet origin in dog owners and evidence for genetic association between strains causing infection in humans and their pets. Epidemiology 28: 1-10. https://doi.org/10.1017/ s0950268813000356

Guilford WG and Strombeck DR, 1996. Gastrointestinal tract infections, parasites, and toxicosis. In: Guilford WG, Center SA et a1. (Eds.) Strombeck's Small Animal Gastroenterology. WB Saunders, Philadelphia pp: 411-432. https://dx.doi.org/10.1111\%2Fj.1939-1676.2003.tb02516.x

Gun-Munro J, Rennie RP, Thornley JH, Richardson HL, Hodge D, Lynch J, 1987. Laboratory and clinical evaluation of isolation media for Campylobacter jejuni. Journal Clinical Microbiology 25: 2274-2277. https://doi.org/10.1128/jcm. 25.12.2274-2277.1987

Hald B, Pedersen K, Wainø M and Madsen M, 2004. Longitudinal study of the excretion patterns of thermophilic Campylobacter spp. in young pet dogs in Denmark. Journal of Clinical Microbiology 42: 2003-2012. https://dx.doi.org/ 10.1128\%2FJCM.42.5.2003-2012.2004

Hascall KL, Kass PH, Saksen J, Ahlmann A, Scorza AV, Lappin MR and Marks SL, 2016. Prevalence of enteropathogens in dogs attending 3 regional dog parks in northern California. Journal of Veterinary Internal Medicine 30: 1838-1845. https://doi.org/10.1111/jvim.14603

Havelaar AH, Kirk MD, Torgerson PR, Gibb HJ, Hald T, Lake RJ, et al, 2015. World Health Organization global estimates and regional comparisons of the burden of foodborne disease in 2010. Plos Medicine 12: e1001923. https://doi.org/10.1371/journal.pmed.1001923

Hermans D, Pasmans F, Messens W, Martel A, Van Immerseel F, Rasschaert G, Heyndrickx $M$, Van Deun $\mathrm{K}$ and Haesebrouck F, 2012. Poultry as a host for the zoonotic pathogen Campylobacter jejuni. Vector Borne Zoonotic Diseases 12: 89-98. https://doi.org/10.1089/vbz.2011.0676
Holmberg M, Rosendal T, Engvall E, Ohlson A and Lindberg A, 2015. Prevalence of thermophilic Campylobacter species in Swedish dogs and characterization of $C$. jejuni isolates. Acta Veterinaria Scandinavica 57: 19. https://doi.org/ 10.1186/s13028-015-0108-0

Iannino F, Donato G, Ruggieri E, Salucci S, De Massis F and Di Giannatale E, 2017. Campylobacter infections, a significant issue of veterinary urban hygiene: Dog-related risk factors. Veterinaria Italiana 53: 111-120. https://doi.org/10.12834/ vetit.904.4615.2

Janssen R, Krogfelt KA, Cawthraw SA, van Pelt W, Wagenaar JA and Owen RJ, 2008. Host-pathogen interactions in Campylobacter infections: the host perspective. Clinical Microbiology Reviews 21: 505-518. https://doi.org/ 10.1128/cmr.00055-07

Kaakoush NO, Castano-Rodriguez N, Mitchell HM and Man SM, 2015. Global epidemiology of Campylobacter infection. Clinical Microbiology Reviews 28: 687-720. https://doi.org/10.1128/cmr.00006-15

Karama M, Cenci-Goga BT, Prosperi A, Etter E, El-Ashram S, McCrindle C, Ombui JN and Kalake A, 2019. Prevalence and risk factors associated with Campylobacter spp. occurrence in healthy dogs visiting four rural community veterinary clinics in South Africa. Onderstepoort Journal of Veterinary Research 86: e1-e6. https://doi.org/10.4102/ ojvr.v86i1.1673

Karshima SN and Bobbo AA, 2016. Isolation and per characterisation of thermophilic campylobacter species in dogs presented to selected veterinary clinics in Jos, Nigeria. Alexandria Journal of Veterinary Sciences 50: 70-77. http://dx.doi.org/10.5455/ajvs.221754

Kiehntopf M, Melcher F, Hanel I, Eladawy H and Tomaso H, 2011. Differentiation of Campylobacter species by surfaceenhanced laser desorption/ionization-time-of-flight mass spectrometry. Foodborne Pathogen Diseases 8: 875-885. https://doi.org/10.1111/j.1469-0691.2011.03468.x

Kittl S, Heckel G, Korczak BM and Kuhnert P, 2013. Source attribution of human Campylobacter isolates by MLST and fla-typing and association of genotypes with quinolone resistance. PLoS One 8: e81796. https://doi.org/10.1371/ journal.pone. 0081796

Koene MG, Houwers DJ, Dijkstra JR, Duim B and Wagenaar JA, 2009. Strain variation within Campylobacter species in fecal samples from dogs and cats. Veterinary Microbiology 133: 199-205. https://doi.org/10.1016/j.vetmic.2008.06.022

Komba E, 2018. Carriage of antimicrobial resistant thermophilic Campylobacter in the intestines of household dogs in Morogoro Municipality, Tanzania. Tanzania Veterinary Journal 33: 24-32.

Kulkarni SP, Lever S, Logan JM, Lawson AJ, Stanley J and Shafi MS, 2002. Detection of Campylobacter species: a comparison of culture and polymerase chain reaction based methods. Journal Clinical Pathology 55: 749-753. https://dx.doi.org/10.1136\%2Fjcp.55.10.749

Kumar R, Verma AK, Kumar A, Srivastava M and Lal HP, 2012. Prevalence of Campylobacter spp. in dogs attending veterinary practices at Mathura, India and risk indicators associated with shedding. Asian Journal Animal Veterinary Advances 7: 754-760. https://dx.doi.org/10.3923/ajava. 2012.754.760

Labarca JA, Sturgeon J, Borenstein L, Salem N, Harvey SM, Lehnkering E, Reporter R and Mascola L, 2002. Campylobacter upsaliensis: Another pathogen for consideration in the United States. Clinical Infectious Diseases 34: e59-e60. https://doi.org/10.1086/340266

Lastovica AJ and le Roux E, 2003. Prevalence and optimal detection of C. upsaliensis in stool specimens. Clinical Infectious Diseases 36: 1624-1625. https://doi.org/ $\underline{10.1086 / 375079}$ 
Lastovica AJ and Skirrow MB, 2000. Clinical significance of Campylobacter and related species other than Campylobacter jejuni and C. coli. In: Nachamkin I, Blaser MJ, eds. Campylobacter. Washington, DC: ASM Press pp: 89-120. https://doi.org/10.1016/0140-6736(90)92282-M

Lastovica AJ, 2006. Emerging Campylobacter spp.: the tip of the iceberg. Clinical Microbiology Newsletter 28: 4956. http://dx.doi.org/10.1016/j.clinmicnews.2006.03.004

Leahy AM, Cummings KJ, Rodriguez-Rivera LD, Hamer SA, Lawhon SD, 2016. Faecal Campylobacter shedding among dogs in animal shelters across Texas. Zoonoses Public Health 63: 515-521. https://doi.org/10.1111/zph.12356

Leonard EK, Pearl DL, Janecko N, Weese JS, Reid-Smith RJ, Peregrine AS and Finley RL, 2011. Factors related to Campylobacter spp. carriage in client-owned dogs visiting veterinary clinics in a region of Ontario, Canada. Epidemiology and Infection 139: 1531-1541. https://doi.org/10.1017/s0950268810002906

Macartney L, Al-Mashat RR, Taylor DJ and McCandlish IA, 1988. Experimental infection of dog with Campylobacter jejuni. Veterinary Record 122: 245-9. https://doi.org/ 10.1136/vr.122.11.245

Mapletoft EK, Allenspach K and Lamb CR, 2018. How useful is abdominal ultrasonography in dogs with diarrhoea? Journal of Small Animal Practice, 59: 32-37. https://doi.org/ $\underline{10.1111 / \text { jsap. } 12780}$

Marks SL and Kather EJ, 2003. Bacterial- associated diarrhea in the dog: a critical appraisal. Veterinary Clinics of North America: Small Animal Practice 33: 1029-1060. https://doi.org/10.1016/s0195-5616(03)00091-3

Marks SL, 2003. Bacterial Gastroenteritis in Dogs \& Cats--More Common Than You Think. World Small Animal Veterinary Association World Congress Proceedings.

Marks SL, Rankin SC, Byrne BA and Weese JS, 2011. Enteropathogenic bacteria in dogs and cats: Diagnosis, Epidemiology, Treatment and Control. Journal of Veterinary Internal Medicine 25: 1195-1208. https://doi.org/10.1111/j.1939-1676.2011.00821.x

Martinez-Anton L, Marenda M, Firestone SM, Bushell RN, Child G, Hamilton AI, Long SN and Le Chevoir MAR, 2018. Investigation of the role of Campylobacter infection in suspected acute polyradiculoneuritis in dogs. Journal of Veterinary Internal Medicine 32: 352-360. https://doi.org/ 10.1111/jvim. 15030

Maunder CL, Reynolds ZF, Peacock L, Hall EJ, Day MJ and Cogan TA, 2016. Campylobacter species and neutrophilic inflammatory bowel disease in cats. Journal of Veterinary Internal Medicine 30: 996-1001. https://doi.org/10.1111/ jvim. 14374

Montgomery MP, Robertson S, Koski L, Salehi E, Stevenson LM, et a1., 2018. Multidrug-Resistant Campylobacter jejuni Outbreak Linked to Puppy Exposure - United States 2016-2018. Morbidity and Mortality Weekly Report 67: 1032-1035. http://dx.doi.org/10.15585/mmwr.mm6737a3

Mughini GL, Smid JH, Wagenaar JA, Koene MG, Havelaar AH, Friesema IH, French NP, Flemming C, Galson JD, Graziani C, Busani L and VAN Pelt W, 2013. Increased risk for Campylobacter jejuni and C. coli infection of pet origin in dog owners and evidence for genetic association between strains causing infection in humans and their pets. Epidemiology and Infection 141: 2526-2535.

Neubauer C and Hess M, 2006. Detection and identification of food-borne pathogens of the genera Campylobacter, Arcobacter and Helicobacter by multiplex PCR in poultry and poultry products. Journal Veterinary Medicine B Infectious Diseases Veterinary Public Health 53: 376-381. https://doi.org/10.1111/j.1439-0450.2006.00991.x

Noreen Z, Siddiqui FM, Zaman G, Noureen N, Hussain A, Ibrahim $\mathrm{M}$ and Bokhari H, 2019. Comparative genomic analysis of Campylobacter jejuni cj255 reveals diverse genetics, pathogenicity determinants and variation in T6SS. Pakistan Veterinary Journal 39: 145-150. http://dx.doi.org/ 10.29261/pakvetj/2019.01

Odendaal MW, de Cramer KG, van der Walt ML, Botha AD and Pieterson PM, 1994. First isolation of Campylobacter jejuni from the vaginal discharge of three bitches after abortion in South Africa. Onderstepoort Journal of Veterinary Research 61: 193-195. https://pubmed.ncbi.nlm.nih.gov/7596570/

Olson P and Sandstedt K, 1987. Campylobacter in the dog: a clinical and experimental study. Veterinary Record 121: 99-101. https://doi.org/10.1136/vr.121.5.99

On SLW, 2013. Isolation, identification and subtyping of Campylobacter: where to from here? Journal of Microbiological Methods 95: 3-7. https://doi.org/10.1016/j. mimet.2013.06.011

Oswald GP, Twedt DC and Steyn P, 1994. Campylobacter jejuni bacteremia and acute cholecystitis in two dogs. Journal of American Animal Hospital Association 30: 165-169. https://dx.doi.org/10.1111\%2Fjvim.13974

Parsons BN, Porter CJ, Ryvar R, Stavisky J, Williams NJ, Pinchbeck GL, Birtles RJ, Christley RM, German AJ, Radford AD, Hart CA, Gaskell RM and Dawson S, 2010. Prevalence of Campylobacter spp. in a cross-sectional study of dogs attending veterinary practices in the UK and risk indicators associated with shedding. Veterinary Journal 184: 66-70. https://doi.org/10.1016/j.tvj1.2009.01.009

Parsons BN, Williams NJ, Pinchbeck GL, Christley RM, Hart CA, Gaskell RM and Dawson S, 2011. Prevalence and shedding patterns of Campylobacter spp. in longitudinal studies of kennelled dogs. Veterinary Journal 190: 249-254. https://doi.org/10.1016/j.tvj1.2010.10.006

Persson S and Olsen KE, 2005. Multiplex PCR for identification of Campylobacter coli and Campylobacter jejuni from pure cultures and directly on stool samples. Journal Medical Microbiology 54: 1043-1047. https://doi.org/10.1099/jmm. $\underline{0.46203-0}$

Petersen RF, Harrington CS, Kortegaard HE and On SLW, 2007. A PCR-DGGE method for detection and identification of Campylobacter, Helicobacter, Arcobacter and related Epsilobacteria and its application to saliva samples from humans and domestic pets. Journal Applied Microbiology 103: 2601-2615. https://doi.org/10.1111/j. 1365-2672.2007.03515.x

Pintar KDM, Christidis T, Thomas MK, Anderson M, Nesbitt A, Keithlin J, Marshall B, Pollari F, 2015. A systematic review and meta-analysis of the Campylobacter spp. prevalence and concentration in household pets and petting zoo animals for use in exposure assessments. PLoS One 10: e0144976. https://doi.org/10.1371/journal.pone.0144976

Pölzler T, Stüger HP and Lassnig H, 2018. Prevalence of most common human pathogenic Campylobacter spp. in dogs and cats in Styria, Austria. Veterinary Medicine and Science 4: 115-125. https://doi.org/10.1002/vms3.93

Rahimi E, Chakeri A and Esmizadeh K, 2012. Prevalence of Campylobacter species in fecal samples from cats and dogs in Iran. Slovenian Veterinary Research 49: 117-122.

Rodrigues CG, Melo RT, Fonseca BB, Martins PA, Ferreira FA, Maria BJ and Rossi DA, 2015. Occurrence and characterization of Campylobacter spp. isolates in dogs, cats and children. Pesquisa Veterinária Brasileira 35: 365370. http://dx.doi.org/10.1590/S0100-736X2015000400009

Rossi M, Hanninen ML, Revez J, Hannula M and Zanoni RG, 2008. Occurrence and species level diagnostics of Campylobacter spp., enteric Helicobacter spp. And Anaerobiospirillum spp. in healthy and diarrheic dogs and cats. Veterinary Microbiology 129: 304-14. https://doi.org/ 10.1016/j.vetmic.2007.11.014

Sahin O, Burrough ER, Pavlovic N, Frana TS, Madson DM and Zhang Q, 2014. Campylobacter jejuni as a cause of canine abortions in the United States. Journal of Veterinary 
Diagnostic Investigation 26: 699-704. https://doi.org/ $10.1177 / 1040638714545112$

Sahin O, Kassem II, Shen Z, Lin J, Rajashekara G and Zhang Q, 2015. Campylobacter in poultry: ecology and potential interventions. Avian Diseases 59: 185-200. https://doi.org/ 10.1637/11072-032315-Review

Selwet M, Clapa T, Galbas M, Slomski R and Porzucek F, 2015. The prevalence of Campylobacter spp. and occurrence of virulence genes isolated from dogs. Polish Journal of Microbiology 64: 73-76. https://pubmed.ncbi.nlm.nih.gov/ 26094320/

Singhal N, Kumar M, Kanaujia PK and Virdi JS, 2015. MALDITOF mass spectrometry: an emerging technology for microbial identification and diagnosis. Frontiers in Microbiology 6: 791. https://doi.org/10.3389/fmicb.2015. $\underline{00791}$

Strother KO, Steelman CD and Gbur EE, 2005. Reservoir competence of lesser mealworm (Coleoptera: Tenebrionidae) for Campylobacter jejuni (Campylobacterales: Campylobacteraceae). Journal of Medical Entomology 42: 42-47. https://doi.org/10.1093/ jmedent/42.1.42

Suchodolski JS, Gossett NM, Aicher KM, Heilmann RM, Xenoulis PG and Steiner JM, 2010. Molecular assay for the detection of Campylobacter spp in canine and feline fecal samples. Journal of Veterinary Internal Medicine 24: 748749.

Sykes J and Marks S, 2013. Campylobacteriosis. In: Canine and Feline Infectious Diseases. 1st Ed, Elsevier Saunders, Philadelphia, PA, USA pp: 452-457.

Taboada EN, Clark CG, Sproston EL and Carrillo CD, 2013. Current methods for molecular typing of Campylobacter species. Journal of Microbiological Methods 95: 24-31. https://doi.org/10.1016/j.mimet.2013.07.007

Tam CC, Higgins CD, Neal KR, Rodrigues LC, Millership SE and O'Brien SJ, 2009. Chicken consumption and use of acid-suppressing medications as risk factors for Campylobacter enteritis, England. Emerging Infectious
Diseases 15: 1402-1408. https://dx.doi.org/10.3201\%2Feid $\underline{1509.080773}$

Tenkate TD and Stafford RJ, 2001. Risk factors for Campylobacter infection in infants and young children: a matched case-control study. Epidemiology and Infection 127: 399-404. https://doi.org/10.1017/s0950268801006306

Thépault A, Rose V, Queguiner M, Chemaly M and Rivoal K, 2020. Dogs and cats: Reservoirs for highly diverse Campylobacter jejuni and a potential source of human exposure. Animals 10: 838. https://dx.doi.org/10.3390\%2 Fani10050838

Tsai HJ, Huang HC, Lin CM, Lien YY and Chou CH, 2007. Salmonellae and campylobacters in household and stray dogs in northern Taiwan. Veterinary Research Communication 31: 931-939. https://doi.org/10.1007/ s11259-007-0009-4

Vandamme P, Dewhirst FE, Paster BJ and On SLW, 2005. Campylobacteraceae, $\mathrm{p}$ 1147-1160. In Garrity GM, Brenner DJ, Krieg NR, Staley JT (ed), Bergey's manual of systematic bacteriology, vol 2 Springer Science, New York, NY. https://dx.doi.org/10.1186\%2F1471-2164-7-167

Weese JS, 2011. Bacterial enteritis in dogs and cats: diagnosis, therapy and zoonotic potential. Veterinary Clinics of North America: Small Animal practice 41:287-309. https://doi.org/10.1016/j.cvsm.2010.12.005

Wolfs TFW, Duim B, Geelen SPM, Rigter A, Thomson-Carter F, Fleer A and Wagenaar JA, 2001. Neonatal sepsis by Campylobacter jejuni: Genetically proven transmission from a household puppy. Clinical Infectious Diseases 32: E97-E99. https://doi.org/10.1086/319224

Workman SN, Mathison GE and Lavoie MC, 2005. Pet dogs and chicken meat as reservoirs of Campylobacter spp. in Barbados. Journal of Clinical Microbiology 43: 2642-2650. https://dx.doi.org/10.1128\%2FJCM.43.6.2642-2650.2005

Yamasaki Y, Nomura R, Nakano K, Naka S, MatsumotoNakano M, Asai F and Ooshima T, 2012. Distribution of periodontopathic bacterial species in dogs and their owners. Archives of Oral Biology 57: 1183-1188. https://doi.org/ $\underline{10.1016 / \text { j.archoralbio.2012.02.015 }}$ 